\title{
1953 年的蘇聯科輿
}

\author{
A. H. 泊斯米揚諾夫
}

我們進入了新的一年, 1953 年。

有歷史意義的蘇聯共產黨第十九次代表大而 的决議、斯大林“蘇聯社會主義經沙問品”的天才 著作和他在黨代表大會閉学時的演說, 以建設共 產主義社會的偉大計劃武裝了我國人民，鼓舞了 所有各國先進人士篇爭取和平、民主和社會主義 而進行鬥爭。

禁聯共產黨十九次代表大會第先淮的蘇維埃 科學提出了一個偉大的目標一一使蘇聯科學在世 界上居第一位。1953年，即第五個斯大林五年計 劃的第三年，蘇維埃學者的主要任務，也是由黨 代表大會所决定下秝的。

共産主義的物質一技術基礎的建設，向許 多工作部門的工作人員們要求着新的答案, 這只 有科學及其產物一一高度技術一一才能提供出 來。在整個國民經㴒中還需要特殊的、與前不同 的、有更深固基礎的動力裝備, 需要與前不同的 更窉的勞動生產华。需要工業和運輸業中各種生 產過程的更高度的機械化、自動化和遠距離捛縱

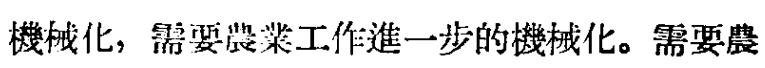
作物的更高的收蓝量和全部農業更慧稔的收成。 需要在先進技衔基礁上更完整地和更全面地使用 原料。需要嶫於蘇聯㘿長着的生產力作更合理 的、更經济的调配。

篇了顺利地完成遭些责無旁貸的任務，蘇維 埃學者們必须枮極地參加解决蘇維埃經濟發展中 的最重要的隔题, 需要更迅速地在科學上總結革

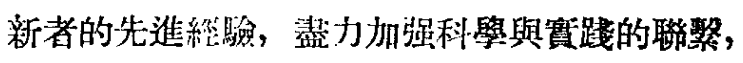
亚使科學工作的成就在䁈践上得到廣泛的應用。 间時, 必须在所有各知雊领域中加强關於有原则 性的理論問题的研究工作。淮步的科學應當保證
將來技術的發展。

鮭聯科學院認篇有頭等重大意義的是，把科 學院各機構的研究成果, 毫不延綏地應用於國民 經㴒中。我們在生產中推廣使用的科學研究成果 的数目一年比一年埇加，但是仍然不够。在1952 年的計劃睃, 研究成果的應用比 1950 年的計劃管 加到兩倍有餘。而 1953 年把已完成的科學研究成 果應用於生產中的計劃则摭大到四倍。

在新的一作中，學者們對於偉大工程的協助 將要大大地堆加起來。蘇聯科學院派到伏酮加河、 第显伯河、顿河等處的工作榢, 將與生產工作者 討論科學理論問題, 總結巨大建設中先進工作者 的經驗。這樣的工作隊將廣泛地開展工作, 特別 是在這些工程本身中開展。

篇了各方面地利用安加拉河的動力資源, 以 求在廉僄電力和地方原料的基礎上發展整鋁工 業、化學工業、磪業和其他工作部門, 需要研究 一系列的新的科學問題。安加拉河的水源是來自 世界最深的貝加爾湖，安加拉河水在秋季往往不 是自水面結水而是在河底結水, 亚引起泛濫, 在 這種困難的地理條件下，水電站的建策是需要地 質學家、凍土學家、水文學家、水系地質學家、 水力技術家等進行研究工作的。

1953 年, 將要十分注意地來研究怎核熱練地

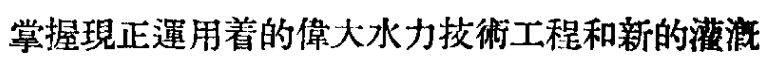
. 與供水系統。

許多地方將建立新的科學中心和筫驗站, 在 那裹科學工作者將要常作地進行關於土壤學、植 物學、㞑業生物學的研究工作, 擬定出掌握新的 灌溉系統的方法。

第了實現斯大林改造自然計劃，非常重要的 
是，對於那些在棋鹤的土壤和氣候條件下，能够 創造出合理的農業技術方法、灌溉方法和逐步培 植森林方法的先進國營農場和集體農莊的經驗, 要加以總結，並在科學上給予論登。對於這一方 面, 生物科學部各研究所和地質地理科學部各研 究所要做很多工作。地理學家和地球物理學家的 任務就是在於加强氣候数化的科學預測工作。

大家都知道，金屈、煤炭、石油、機器製 造是工業中的領導部門, 通是工業中的主要骨 幹。

䔉聯科學院有很大可能性援大有關遭些技衍 部門的科學研究工作。冶金研究所得到了新建築 的大廈, 可以開展廣泛的工作, 例如研究加强冶 金過程的辦法, 求得具有各種用途的新合金, 研 究稀有金屬在冶金業中的利用, 以及研究怎樣在 實践上應用那些至今不大知名的而可大量得到的 並有害贵的技街特性的金屬（如鈦等金屬）。

古柏金石油研究所在 1953 年, 對於石油的開 探和提淿, 對於石油產品的合理利用, 將要進行 科學研究工作。許許多多的地翼調䄳隊将要從莫

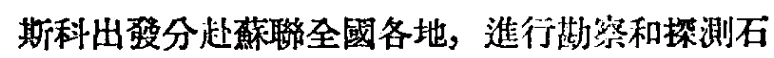
油的新産地。蘇聯科學院有雨個研究所一一探磄 研究所和碳物然料研究所一一和一個獨立的煤岸

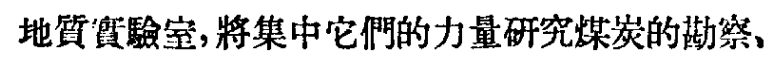
探测和開探的問題, 以及研究關於煤岑的保存、 利用和加工的問題。

因第替伏爾加河上偉大共産主義建設工程設 計和彆造一些巨大水力渦輪和渦輀發電機, 引起 了一系列的問題需要解决, 機械工程研究所將繼 綧谁行造方面的研究工作。在機器製造的理論方 面和生產過程自動化的科學原理方面, 研究所也 將要展開科學研究。

自動機及遠距離操縱機研究所將要從事政究 各工業部門和各聯合動力系統中的自動化管理、 操緥和調節的理論以及技衔器材的問題。

在物理、數學和化學家面前㨢着一些重要任 䅂。我們的物理學家, 首先是研究原子核物理學、 無線電和電子學、光學、發光作用理論的那些專 家學者, 將要繼續進行那些對於將來的技街有决 定性意義的重要研究工作。

對於我國有害富䓇藏的稀有的和分散的元 素, 在地球化學和化學方面的研究工作將要窝大。
邆樣可以估計如何愅大它們在工業上應用的箱 圍, 並建立應用它們的工業新部門。

大家都知逆, 丁二烯合成橡脍並不等於自然 橡膠。自然橡膠在某些技術特性上戝於合成橡膠, 但是還有不如合成橡翏的地方。化學家的任務是 研究出製造合成橡膠的工業方法, 使其在各方面 皆優於自然橡膠。塑料和人造樹脂在生活中應用 很廣, 從翏价、雨衣、䙮子一直到汽車和飛機上。 的零件都有應用之處。我們的任務是改進人造塑 料的技術，使共在堅固性上能够代替金屬。當前 首先要解决從容易得到的石油瓦斯中製造合成塑 料和樹脂的問題。

數學中所有新的部門都是篇科學和技街服務 的。蘇維埃數學在世界科學中佔很高的地位, 它 是篇蘇維埃技術服務的。最新的技術也供給了數 學以利用機械進行最複䧴計算工作的新的可能 性。因而使得力學、物理學和各種汥街科學部門 中以前難以解决的問题得到解决。在新的一年 裹, 在這些部閅中, 篇蕉聯數學家打開了廣潤的 園地。

最近幾年以來, 在研究天體起源和發屡規律 方面獲得了主越的成就。在蘇聯科學院天文學委 員會的新年計劃中佔㙷著地位的, 是對於行星和 恒星的演化阔题的進一步的研究。

在社會科學的領域中，科學研究工作的主要 方針是由今天的基本任務所规定的, 這個基本任 務就是使蘇維埃社會從诖會主義逐漸過渡到共産

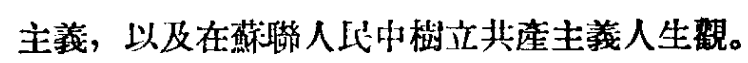

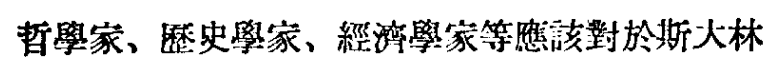

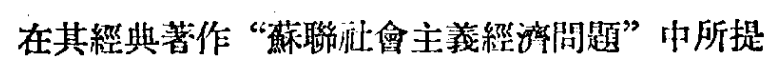
出的問題, 予以创造性的發拝，這是有重大意義 的; 同時還要出版一些闻明鼓一天才著作的科學 書籍和科學普及書籍。

在經深學研究所 1953 年工作計劃中佔主㝵 地位的是對蘇聯社會主義經㴼發展規律的研究。 關於這方面, 要進行準備出版一些棕合性的苦作 和專題論文。該研究所於新年後䪙將要出版關於 現代資本主義體系總危機加深的問題、關於美怗 國主義的侵略問題、以及關於許多國家中工人階 級狀况的問題的萎作。

深入地揭穿篇戰爭販子服移的瑟婊的凟産階 攵思想體系，通將是中心工作之一。新的科學研 
究工作瑔玟力於在思想上.打碎美國與英國的社會

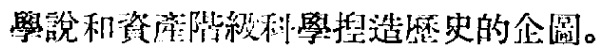

蘇聯利舅院全體科學工作人員將要參加“棓 證唯物主義四現代自然科學”這一大規模著作的 編輯工作。

在利學砄究工作的計劃中，也注意到蘇聯共 福裳第十九次代表大會所提出的閣於法律學方面 的原则性意岂。法律研究所原備皘極參加全蘇法 典的絧隹工作。

在歷史罨者的 1953 年計劃中, 大力地注意到 寫出多聟集的苦作，無論在蘇聯史或在外國史的 研究領域中，這些著作的察作都將以概括已有成 就亚進一步發展蘇維埃歴史科學篇原则。

在東方學範四落中，將研究東方各國家的新的 歴史, 首先研究中國、朝鮮，以及東南亞各國, 並研究東方各國的經濟和這些國家的民族文學與 語言。

根據斯大林的天才著作 “馬克思主義與語言 學問題”的觀點，我們的語言學家將繼續研究關 於語言與思維的問題、語言文化問題、語言史與 民族史密切聯系的問題、以及語言發展的內在規 律問題。

在生物科學方面，要特別注意到總結若干研 究所的頞驗工作所歸納的重要理論問題: 包括關 於常態和疾態中生理過程的規律問題，關於非細 胞形態和細胞形態生活物質的發展規律問題, 關 於遺傳性及其變異性的問題，關於蛋白質及新陳 代謝問題, 關於組織與器官再生問題, 關於新品 種的形成問题等。

巴甫洛夫生理學研究所將發展關於高級神經 活動的巴甫洛夫學說，因而進行大量的工作以研 究大腦皮質對於有機體內在機能的調節作用。

我們生物學者一年比一年地加强了和實践的 聯系。生物科學部各研究所棕合地研究食品工業 新技衍的原则上的改淮問題。巴赫生物化學研究 所將研究可以决定長年保存的酒的品筫的物筫、 研究香橪酒的赸泡作用、研究茶的芬香性, 第維 生素工業攻求的的原料來源。

在蘇維埃學者們面前提出來了光策的任務， 要求展開研究工作的新方向。

凡是能够迅速推動廣大科學戰綫前進的，能 够第全部蘇維埃科學一往遖前的運動開開新道路

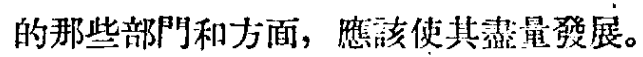

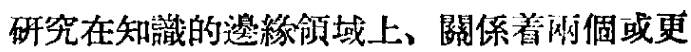
多個科學科目的理論問題，這是有重要意義的。 科學在這裏的發展常常是最有力的, 生物化學、 地球物理學、生物物理學、生物地理化學等問題 就是這樣的例子。

蘇聯科學院生物物理學研究所的設立就是第 了遊合這樣的任務。新研究所的任務是研究物理 因素對生物的作用一一生物物理的生活現像基礎 的嫢律性和作用過程。在當前的一年，垺要應用 一一現代最精密的害驗方法，從各個方面來研究 一一系列的新的物理因素, 如離子化放射、高頻率 超短電磁波、超音波與超强馨豆刺激等。同時， 在生理學者方面, 研究視覺器官和聡覺器官活動 的生物物理基礎。還要研究生物照明術問題, 逼 問題和合理化照明問題相關聯。

汥有深入的原則性的批評和自我批評, 汥有 對于各個知識部門在發展道路上引起争論的問題 的創造性的討論，蘇維埃先進科學的一往直前的 發展是不可想像的。所以, 特别重要的是, 必須 保證使科學討論在高度水本上進行。1953 年所要 淮行的討論會是: 關於數學、土壤學、古生物學、 岩石學、經濟地理學等方面，以及關於宇宙棧問 題, 關於機器和機栈的原理問題等。

作第科學工作高浱的指標的蘇聯科學院的出 版活動，一年比一年撗大起來。1953 年, 我們計 劃出版 16,600 印刷張的關於所有各知織部門的科 學著作。

十儿次黨代表大會在蘇維埃學者們面前所提 出的巨大任務，隹該用我國的全部科學力量來完 成; 我們要竭盖一切方法來提高科學工作，不僅 是莫斯科和列穿格勒的科學工作，並且提高所有 加盟共和國各科學院、蘇聯科學院各分院、各工 業中的研究所，以及所有 887 所高等學校的科學 工作。在這方面，科學工作的報導是有重大作用 的。由於科學發展的規模宏大和有關科學問題的 世界刊物數目的增加，科學工作者日益困難地在 這科學文缺的大海裹，找到他工作上需要的具能 材料。

1952 年, 在蘇聯科學院的出版局下設立了悬 術報導處。這個機構的首要任務是䌰輯一些學術 [下接第42頁] 